\title{
STRATEGI ORANG TUA DALAM MENGAJAR DAN MENDIDIK ANAK DALAM PEMBELAJARAN DIRUMAH SELAMA PANDEMI COVID-19
}

\author{
Nunung Oktaviani ${ }^{1,}$ Inong Sri Rahayu ${ }^{2}$,Liza Wahyuni ${ }^{3}$ \\ ${ }^{1}$ Mahasiswa Program Ilmu Keperawatan STIKes Muhammadiyah Lhokseumawe, Indonesia, 23004 \\ ${ }^{2}$ Dosen Ilmu Keperawatan STIKes Muhammadiyah Lhokseumawe, Indonesia, 23004 \\ ${ }^{3}$ Dosen Ilmu Keperawatan STIKes Muhammadiyah Lhokseumawe, Indonesia, 23004 \\ Correspondence : israyu83@gmail.com
}

\begin{abstract}
Based on the data of the previous survey conducted by researchers on 10 mothers who have school-age children, 6 of them said their children were not interested in learning at home and 4 others were interested in learning at home. The objective of this research was to see how the strategies of parents in teaching and educating children in learning at home during the Covid-19 pandemic in Gampong Meunasah Cut, Peudada District, Bireuen Regency.This research method was descriptive and it was conducted in Gampong Meunasah Cut, Peudada District, Bireuen Regency. The samples were 40 respondents taken through total sampling technique. Data collection was carried out on August 11 to 15, 2021 and obtained through the distribution of question naires. The results of the research showed that the strategy of the discussion method obtained 30 respondents $(75.0 \%)$, the playing method was 28 respondents $(70.0 \%)$, the storytelling method was 28 respondents $(70.0 \%)$, the drawing method was 27 respondents $(67.5 \%)$ and the discussion method was 21 respondents (52.5\%).Parents are expected to be friends in telling stories, playing, learning, discussing with children and supporting children in the learning process, especially in the pandemic condition today, parents are also expected to always play an active role in teaching and educating their children.
\end{abstract}

\section{Keywords: Strategy, Teaching and Educating, Covid 19}

\begin{abstract}
ABSTRAK
Berdasarkan survey data awal yang dilakukan peneliti pada 10 orang ibu yang memiliki anak usia sekolah diperoleh hasil 6 diantaranya mengatakan anaknya tidak tertarik saat melakukan pembelajaran dirumah dan 4 lainnya tertarik melakukan pembelajaran di rumah.Penelitian ini bertujuan untuk melihat bagaimanakah strategi orang tua dalam mengajar dan mendidik anak dalam pembelajaran dirumah selama pandemi Covid-19 di Gampong Meunasah Cut Kecamatan Peudada Kabupaten BireuenMetode penelitian ini bersifat deskriptif dengan jumlah responden 40 responden di gampong meunasah cut kecamatan peudada kabupaten bireuen dengan mengunakan tekhnik total sampling, pengumpulan data dilakukan pada tanggal 11 sampai dengan 15 agustus 2021. Data didapatkan melalui pembagian kuesioner.Hasil penelitian didapatkan Strategi metode diskusi diperoleh sebanyak 30 respon den(75,0\%), metode bermain sebanyak 28 responden(70,0\%),metode bercerita sebanyak 28 responden (70,0\%), metode gambar sebanyak 27 responden $(67,5 \%)$,dan metode diskusi sebanyak 21 responden $(52,5 \%)$ Orang tua diharapkan dapat menjadi teman bercerita bermain belajar dan diskusi dengan anak dan mendukung anak dalam proses pembelajaran apalagi dalam kondisi pandemi seperti ini,orang tua juga diharapkan selalu berperan aktif dalam mengajar dan mendidik anaknya.
\end{abstract}

Kata kunci :Strategi, Mengajar dan mendidik, Covid-19 


\section{PENDAHULUAN}

Coronavirus 2019 atau Covid-19 adalah jenis penyakit baru yang disebab kan oleh infeksi sindrom pernafasan akut parah dengan nama Corona virus 2 (SARS) COV2) atau yang biasa disebut dengan novel coronavirus (2019-nCoV) (Singhal, 2020). Penyakit ini ditularkan melalui droplet (percikan) dari orang yang terinfeksi covid19 ,droplet ini bisa menular saat orang yang sudah terinfeksi berbicara, batuk dan bersin di dekat orang lain. Selain itu, penyakit ini juga dapat ditularkan melalui kontak fisik seperti bersentuhan atau berjabat tangan dengan penderita serta tersentuh bagian wajah, mulut, dan hidung tangan yang telah terpapar virus corona (Singhal, 2020).

Gejala klinis yang sering di timbulk an oleh infeksi virus ini hampir sama dengan gejala flu biasanya seperti demam, batuk, pilek, radang tenggorokan, nyeri otot, sakit kepala hingga komplikasi parah yaitu seperti diare dan pneumonia yang berujung pada kematian (Huang et al,2020).Menurut Kemenkes RI (2020) orang yang rentan terin feksi virus ini adalah orang tua dan orang yang memiliki riwayat penyakit bawaan seperti asma, diabetes, gagal jantung dan tekanan darah tinggi. Sedangkan pada anakanak, Mereka juga termasuk dalam kelom pok usia yang sangat mudah dan juga rentan menyebarkan Covid-19. Beberapa anak yang terinfeksi Covid-19 biasanya tidak menunjuk kan gejala infeksi (Zimmer mann dan Curtis ,2020)

Menurut data dari WHO (2021) Virus corona telah menginfeksi 88.368 .358 orang di seluruh dunia. Di antara mereka, 63.454.087 dinyatakan sembuh dari infeksi. Pada saat yang sama, virus tersebut telah menewaskan 1.904.030 orang di seluruh dunia. Amerika Serikat tetap menjadi negara dengan infeksi virus korona terbanyak di dunia. Jumlah kasus positif Covid-19 yang terkonfirmasi secara nasional mencapai 22.053.988, 196.372 kasus per hari. Amerika Serikat juga merupakan negara dengan jumlah kematian tertinggi di dunia, dengan 373.087 kematian dilaporkan. Sementara itu, negara itu mencatat 1.086.277 orang yang dinyatakan positif Covid-19 dan telah pulih.

Di Indonesia, penyebaran Covid-19 tidak ada kasus infeksi antara Desember 2019 hingga Februari 2020, namun pada 2 Maret 2020, dua kasus pertama dipastikan terinfeksi Covid-19 yaitu seorang ibu dan anaknya yang berusia 64 tahun dan 31 tahun (Djalante et al.2020). Menurut Kementerian Kesehatan Repuplik Indonesia, pada 25 April 2020, jumlah kasus positif Covid-19 di Indonesia meningkat menjadi 8.607. Dari kasus tersebut, 1.042 sembuh dan 720 orang meninggal (Achmad, 2020).

Melihat jumlah kasus covid-19 yang begitu besar, pemerintah segera memperkuat rencana dan kebijakannya guna mengen dalikan penyebaran Covid-19. Untuk itu, pemerintah telah bertindak cepat untuk me mutus mata rantai penyebaran Covid-19. Kebijakan yang telah ditetapkan pemerintah untuk menangani penyebaran Covid-19 antara lain pembatasan aktivitas, persyaratan menjaga kebersihan diri, social distancing, jaga jarak, isolasi wilayah, bekerja dari rumah karyawan dan membatasi mobilitas atar wilayah berbeda (BCC,2020).

Pemerintah Aceh pertama kali me laporkan kasus positif di provinsi Aceh pada tanggal 23 maret 2020. Di aceh jumlah positif covid-19 terkonfirmasi sebanyak 9.403 jiwa pada tahun 2021, yang sedang menjalani perawatan sebanyak 1.284 jiwa, yang telah dinyatakan sembuh sebanyak 7.739 jiwa dan yang telah dinyatakan meninggal sebanyak 380 jiwa( Dinas Kesehatan Provinsi Aceh,2021).

Berdasarkan data dari Dinas Keseh atan Kabupaten Bireuen terdapat total kasus sebanyak 471 kasus di daerah bireuen sedangkan berdasarkan pengambilan data di daerah peudada kabupaten bireuen terdapat sebanyak 16 kasus positif covid-19 di an taranya 3 laki-laki dan 13 orang perempuan serta 1 orang meninggal dunia. Berdasarkan laporan yang telah di dapatkan penyebaran covid-19 di daerah peudada terjadi karena banyaknya orang-orang yang melakukan perjalanan tanpa memperhatikan protokol 
kesehatan( Dinas Kesehatan Kabupaten Bireuen,2021)

Penyebaran Virus Corona atau Covi d-19 menjadi ancaman bagi manusia tidak terkecuali aktivitas setiap orang dalam pen didikan. Di tengah penyebaran virus ini, pemerintah mengeluarkan regulasi setiap orang menjaga jarak dari semua orang, termasuk guru dan teman siapa saja yang pergi ke sekolah. Menurut peraturan ini, Menteri Pendidikan memberikan kebijakan untuk membuat semua sekolah atau kegiatan mengajar memiliki sifat jumlah orang yang banyak harus dihindari, oleh karena itu, seluruh sekolah harus diliburkan sementara dan dialihkan ke sistem untuk belajar di rumah secara daring atau online ( Saputra ,2020)

Kegiatan belajar dari rumah di selen ggarakan secara daring (dalam jaringan). Kegiatan belajar anak tersebut dilak sanakan di rumah dan menjadi tanggung jawab orangtua. Kesiapan belajar dari rumah ini dapat dilihat dari bagaimana orangtua dalam membimbing anak selama belajar di rumah. Alternatif pembelajran secara daring ini dilaksanakan dengan cara pemberian tugas oleh guru kepada murid melalui grup WhatsApp, aplikasi Google Classroom atau melalui platform Google Meet, Google Zo om, dan sebagainya untuk mengintegrasikan teknologi dalam proses belajar mengajar secara virtual (Okmawati \& Tanjak, 2011).

Strategi yang dapat digunakan orang tua dalam mendidik dan mengajar anaknya dirumah adalah dengan metode mengguna kan banyak gambar daripada kata , meng gunakan metode bermain, menggunakan metode diskusi, menggunakan metode demo nstrasi, tehknik atau metode bercerita dan bisa dengan penataan ruang belajar yang nyaman untuk anak agar anak betah bela jar,membuat tugas dan tidak mudah bosan (Kementrian Pendidikan dan Kebudayaan ,2016).

Meskipun sekarang sudah memasuki masa new normal dunia pendidikan harus tetap memanfaatkan teknologi untuk menu njang efektivitas pembelajaran. Mengingat, empat bulan terakhir ini kita masih meng gunakan sistem pembelajaran daring. Tentu nya ini menimbulkan reaksi dari berbagai pihak, terkhusus, pihak orang tua peserta didik. Kekhawatiran dan kecemasan akan menjadi kendala bagi siswa untuk belajar. Kita tahu, bahwa hingga sampai hari ini kasus penyebaran Covid-19 di Indonesia masih belum berhenti. Oleh karena itu, kebijakan tersebut perlu di pertimbangkan oleh berbagai pihak. Setidaknya dalam proses pembelajaran dibuka kembali telah memenuhi syarat protokol kesehatan Covid19. Walaupun pembelajaran dilakukan secara daring, pengajar tetap harus memasukkan kearifan lokal dalam pembelajaran (Wahyu ningsih dkk.,2020).

Penelitian yang dilakukan oleh (Yulianingsih dkk,2020) yang berjudul Keter libatan Orangtua dalam Pendampingan Bela jar Anak selama Masa Pandemi Covid-19 yang dilakukan di PAUD SKB Cerme Gresik menunjukan hasil yang sangat baik. Berda sarkan hasil penelitian pada sub variabel pendampingan belajar anak sangat baik dengan persentase sebesar $82,59 \%$. Hasil tersebut didukung dengan adanya kesesuaian hasil pada setiap sub variabel yaitu pada sub variabel peran orangtua dan pendampingan belajar anak.

Hasil penelitian yang dilakukan oleh (Alpian dkk, 2020)yang berjudul Sosialisasi Peran Orang Tua di Masa Pandemik Covid19 dalam pembelajaran daring bagi anak usia sekolah dasar di Desa Cikalongsari Karawang didapatkan hasil Peran orang tua dalam men dampingi kesuksesan pada pendidikan anak terutama pendidikan anak usia Sekolah Dasar Desa Cikalongsari selama belajar di rumah menjadi sangat di penting karena pada masa pandemi Covid-19 ini anak lebih cenderung memiliki banyak waktu belajar di rumah. Selain itu komunikasi yang terjalin antara orang tua dan guru sangat di penting pada masa pandemik seperti ini karena guru dan orang tua merupakan kunci dari kesuksesan pembelajaran jarak jauh atau pembelajaran daring. Tanpa adanya komunikasi yang dilakukan oleh orang tua dan guru, tentu 
proses pendidikan yang di harapkan tidak akan terwujud. Adapun bentuk komunikasi guru dengan orang tua yang dilaksanakan di Desa Cikalongsari ini meliputi Kerjasama yang dilakukan dengan menggunakan sebuah aplikasi

Hasil penelitian yang dilakukan oleh (rahmania dkk,2020)yang berjudul Strategi Orang Tua dalam Pendampingan Belajar Anak Selama Pandemi Covid-19 mengide ntifikasikan bahwa kurangnya Orang tua dal am memperhatikan pendampingan belajar anaknya dengan menyerahkan kepada kakek, om atau tante, maupun kepada sang istri saja. Cara mendampingi belajar dengan metode permainan, bercerita, dan penugasan serta adanya pengawasan saat belajar.

Berdasarkan survey data awal yang dilakukan peneliti di desa Meunasah Cut kecamatan peudada kabupaten bireuen ter dapat sebanyak 40 orang ibu yang memiliki anak usia sekolah dasar dan sedang mela kukan pembelajaran dari rumah. Dari hasil wawancara didapatkan 10 orang ibu, 6 di antaranya mengatakan anaknya tidak tertarik saat melakukan pembelajaran dan pendi dikan selama dirumah dikarenakan merasa bosan,jarang bermain dengan teman dan tidak bertemu dengan orang lain selain orang tua dan keluarganya. Sedangkan 4 ibu lain nya mengatakan anak sangat semangat saat melakukan pembelajaran selama pan demi Covid-19 dirumah dikarenakan mereka tidak perlu keluar rumah untuk bermain dan bisa sering bermain gadget dirumah.

\section{METODELOGI}

Penelitian ini bersifat deskriptif yaitu untuk melihat gambaran strategi orang tua dalam mendidik dan mengajar anak selama pandemi covid-19.

a. populasi

Populasi dalam penelitian ini adalah orang tua yang memiliki anak usia sekolah yang berjumlah sebanyak 40 anak

b. Sampel

Sampel adalah bagian dari populasi yang akan diteliti untuk menentukan jumlah responden. Dalam penelitian ini, tekhnik yang digunakan untuk pengambilan sampel adalah total sampling yaitu tekhnik pengambilan sampel seluruh populasi dijadikan sampel (Nursalam,2015). Dalam penelitian ini yang akan dijadikan sampel adalah orang tua yang memiliki anak usia sekolah yang berjumlah sebanyak 40 anak

\section{ANALISA DATA}

Penelitian ini bersifat deskriptif, maka dalam analisisnya tidak menggunakan perhitungan uji statistik tetapi hanya berda sarkan distribusi frekuensi di setiap variabel statistiknya yang digunakan untuk perhitu ngan hasil ukur yang kemudian dipresen tasikan (Machfoedz, 2010)

\section{HASIL PENELITIAN}

Analisa Univariat

\section{a. Data Demografi}

Tabel 1. Distribusi Frekuensi Demografi Responden $(\mathrm{n}=40)$.

\begin{tabular}{llcc}
\hline $\mathrm{N}$ & $\begin{array}{l}\text { Umur orang } \\
\mathrm{o}\end{array}$ & Frekuensi & Persentase \\
\hline 1. & $26-35$ tahun & 10 & 25,0 \\
\hline 2. & $36-45$ tahun & 25 & 62,5 \\
\hline 3. & $46-55$ tahun & 5 & 12,5 \\
\hline
\end{tabular}

Berdasarkan tabel 1 diperoleh hasil bahwa frekuensi terbanyak besar usia yaitu 36-45 tahun dengan frekuensi sebanyak 25 orang $(62,5 \%)$.

Tabel 2 Distribusi Frekuensi Pekerjaan Responden $(\mathrm{n}=40)$.

\begin{tabular}{|c|c|c|c|}
\hline $\begin{array}{l}\mathrm{N} \\
\mathrm{O}\end{array}$ & $\begin{array}{l}\text { Pekerjaan } \\
\text { orang tua }\end{array}$ & Frekuensi & Persentase \\
\hline 1. & PNS & 25 & 62,5 \\
\hline 2. & IRT & 10 & 25,0 \\
\hline 3. & Pedagang & 5 & 12,5 \\
\hline
\end{tabular}

Berdasarkan tabel 2 pekerjaan orang tua ter banyak adalah PNS dengan frekuensi 25 orang $(62,5 \%)$. 
Tabel 3 Distribusi Frekuensi Penddikan Responden $(n=40)$.

\begin{tabular}{llcc}
\hline N & $\begin{array}{l}\text { Pendidikan } \\
\text { orang tua }\end{array}$ & Frekuensi & Persentase \\
\hline 1. & Rendah & 0 & 37,5 \\
\hline 2. & Menengah & 15 & 37,5 \\
\hline 3. & Tinggi & 25 & 62,5 \\
\hline
\end{tabular}

Berdasarkan tabel 3 Pendidikan orang tua paling banyak yaitu pendidikan tinggi seban yak 25 orang $(62,5 \%)$.

a. Metode gambar

Tabel 4:Distribusi frekuensi Metode Gambar Strategi Orang Tua dalam Pembelajaran dirumah Selama Pandemi Covid-19 ( $\mathrm{n}=40)$.

\begin{tabular}{llcc}
\hline $\begin{array}{l}\text { Metode } \\
\text { gambar }\end{array}$ & Frekuensi & Persentase \\
\hline 1. & ada & 27 & 67,5 \\
\hline 2. & tidak ada & 13 & 32,5 \\
\hline
\end{tabular}

Berdasarkan tabel 4 diatas dapat dili hat bahwa mayoritas penerapan strategi orang tua dalam mengajar dan mendidik anak dengan menggunakan metode gambar seban yak 27 responden $(67,5 \%)$, dibanding kan dengan yang tidak menggu nakan sebanyak 10 responden $(32,5 \%)$.

b. Metode Bermain

Tabel 5 :Distribusi frekuensi Metode Bermain Strategi Orang Tua dalam Pembelajaran dirumah Selama Pandemi Covid-19 $(n=40)$.

\begin{tabular}{lccc}
\hline & $\begin{array}{c}\text { Metode } \\
\text { Bermain }\end{array}$ & Frekuensi & Persentase \\
\hline 1. & ada & 28 & 70,0 \\
\hline 2. & tidak ada & 12 & 30,0 \\
\hline
\end{tabular}

Berdasarkan tabel 5 diatas dapat dilihat bahwa mayoritas penerapan strategi orang tua dalam mengajar dan mendidik anak dengan menggunaka metode bermain seban yak 28 responden $(70,0 \%)$, dibandingkan den gan yang tidak menggunakan sebanyak 12 responden $(30,0 \%)$

\section{c. Metode Diskusi}

Tabel 6 :Distribusi Frekuensi Metode Diskusi Strategi Orang Tua dalam Pembelajaran dirumah Selama Pandemi Covid-19 ( $\mathrm{n}=40)$.

\begin{tabular}{llcc}
\hline & $\begin{array}{l}\text { Metode } \\
\text { Diskusi }\end{array}$ & Frekuensi & Persentase \\
\hline 1. & ada & 30 & 75,5 \\
\hline 2. & tidak ada & 10 & 25,0 \\
\hline
\end{tabular}

Berdasarkan tabel 6 diatas dapat dili hat bahwa mayoritas penerapan strategi orang tua dalam mengajar dan mendidik anak dengan menggunakan metode diskusi seban yak 30 responden $(75,0 \%)$, diban dingkan dengan yang tidak menggunakan sebanyak 10 responden $(25,0 \%)$.

\section{d. Metode Demonstrasi}

Tabel 7 :Distribusi Frekuensi Metode Demon strasi Strategi Orang Tua dalam Pembelajaran dirumah Selama Pandemi Covid-19 ( $\mathrm{n}=40)$.

\begin{tabular}{|c|c|c|}
\hline $\begin{array}{c}\text { Metode } \\
\text { Demonstrasi }\end{array}$ & Frekuensi & Persentase \\
\hline 1. ada & 21 & 52,5 \\
\hline 2. tidak ada & 19 & 47,5 \\
\hline
\end{tabular}

Berdasarkan tabel 7 diatas dapat dilihat bahwa mayoritas penerapan strategi orang tua dalam mengajar dan mendidik anak dengan menggunakan metode demonstrasi sebanyak 21 responden (52,5\%),dibanding kan dengan yang tidak menggunakan seban yak 19 responden $(47,5 \%)$

e. Metode Bercerita

Tabel 8:Distribusi Frekuensi Metode Berceri ta Strategi Orang Tua dalam Pembelajaran di rumah Selama Pandemi Covid-19 ( $n=40)$. 


\begin{tabular}{|c|c|c|}
\hline $\begin{array}{c}\text { Metode } \\
\text { Bercerita }\end{array}$ & Frekuensi & Persentase \\
\hline 1. ada & 28 & 70,0 \\
\hline 2. tidak ada & 12 & 30,0 \\
\hline
\end{tabular}

Berdasarkan tabel 8 diatas dapat dilihat bahwa mayoritas penerapan strategi orang tua dalam mengajar dan mendidik anak dengan menggunakan metode bercerita se banyak 28 responden (70,0\%), diban dingkan dengan yang tidak menggunakan sebanyak 12 responden $(30,0 \%)$.

\section{PEMBAHASAN}

Berdasarkan hasil penelitian pene litian yang dilakukan oleh peneliti dengan jumlah 40 responden didapatkan hasil yang menggunakan metode gambar sebanyak 27 responden $(67,5 \%)$,yang menggunakan me tode bermain sebanyak 28 responden $(70,0$ $\%)$,yang menggunakan metode diskusi se banyak 30 responden(75,0\%), yang meng gunakan metode demonstrasi sebanyak 21 responden $(52,5 \%)$, dan yang menggunakan metode bercerita sebanyak 28 responden (70,0\%). Dan selebihnya menjawab tidak menggunakan metode tersebut.

Dalam proses atau kegiatan pembe lajaran, masing-masing orang tua memiliki cara berbeda dalam menanggapi pelaksanaan sistem belajar online. Kegiatan dari proses belajar di rumah, ternyata mampu memberi respon yang tidak sama, terkadang para siswa akan bosan belajar di rumah, karena ter kendala akses jaringan dan terbatasnya kuota yang digunakan, kemudian kurang kon sentrasi terhadap apa yang sedang dikerjakan ketika akan online, dan bagaimana agar mereka tetap survive selama belajar di rumah. Dengan adanya belajar dari rumah, seti daknya para siswa bisa belajar sejak awal, bahwa posisi perencanaan dalam melakukan belajar di rumah lebih terencana dengan baik, serta lebih terfokus dalam kegiatan yang positif. (Saputra, 2020)
a. Metode gambar
Dari 40 responden yang menerapkan metode gambar sebanyak 27 responden
$(67,5 \%)$ dan yang tidak menerapkan seban yak 13 responden(32,5\%). Jadi orang tua yang lain tidak menerapkan metode gambar dan mereka juga menerapkan metode pembe lajaran yang lainnya.

Berdasarkan teori dari muhammad ramli(2012) Gambar ini dapat disajikan secara fotografik untuk anak, misalnya gambar tentang manusia, binatang, tempat, atau objek lainnya yang ada kaitannya dengan bahan/isi tema yang diajarkan jadi anak akan cenderung lebih paham dan antusias dalam belajar. Metode Gambar ini ada juga yang sifatnya tunggal dan ada juga yang saling berhubungan satu dengan lainnya,keuntungan yang bisa diperoleh dengan menggunakan metode gambar ini diantaranya media ini dapat menerjemahkan ide/gagasan yang sifat nya abstrak menjadi lebih konkrit mudah dalam menggunakannya dan tidak memen rlukan peralatan lain, tidak mahal bahkan mungkin tanpa mengeluarkan biaya untuk pengadaannya,dapat digunakan pada setiap tahap kegiatan pendidikan dan semua tema pembelajaran .

Hasil ini sejalan dengan penelitian nurhayati(2013)yaitu pelaksanaan pembelaja ran menulis deskripsi dengan menggunakan media gambar dapat meningkatkan kete rampilan siswa dalam menulis deskripsi, terlihat dari persentase keterlaksanaan pem belajaran yang mengalami peningkatan secara signifikan, yaitu dari siklus I rata-rata ke terlaksanaan $93,75 \%$ dengan nilai keter capaian 82,65 menjadi rata-rata keterlak sanaan $100 \%$ dengan nilai ketercapaian 94,65 pada siklus II. Ketuntasan belajar siswa secara klasikal juga pada siklus II telah mencapai persentase yang telah ditetapkan pada indikator keberhasilan, yaitu $\geq 75 \%$ siswa telah mencapai KKM $(\geq 75)$ dengan kriteria sangat tinggi yaitu $\geq 80 \%$, maka dapat disimpulkan bahwa penggunaan media gambar dapat meningkatkan keterampilan siswa dalam belajar 


\section{b. Metode Bermain}

Dari 40 responden yang menerapkan sebanyak 28 responden(70,0\%)dan yang tidak menerapkan sebanyak 12 responden $(30,0 \%)$.

Berdasarkan teori hibana S.Rahman Bermain merupakan tuntutan dan kebutuhan yang esensial bagi anak usia dini. Melalui bermain sambil beljar anak akan dapat memuaskan tuntutan dan kebutuhan perkem bangan dimensi motorik, kognitif, kreativitas, bahasa, emosi, sosial, nilai dan sikap,dapat berlatih menggunakan kemampuan kognitif nya untuk memecahkan berbagai masalah, misalnya mengukur berat, membandingkan, mencari jawaban yang berbeda,dapat meng embangkan kreativitasnya, yaitu melaku kan kegiatan yang mengandung kelenturan, me manfaatkan imajinasi atau ekspresi diri, dan juga kegiatan-kegiatan pemecahan masalah, dapat melatih kemampuan bahasanya dengan cara mendengarkan beraneka bunyi, mengu capkan suku kata atau kata, memperluas kosa kata, berbicara sesuai dengan bahasa Indo nesia dan sebagainya,dapat meningkatkan ke pekaan emisonya dengan cara mengenalkan bermacam perasaan, mengenalkan perubahan perasaan, membuat pertimbangan, menum buhkan kepercayaan diri dan dapat mengem bangkan kemampuan sosialnya seperti mem bina hubungan dengan teman sebaya, men yesuaikan diri dengan teman sebaya, dapat memahami tingkah lakunya sendiri, paham bahwa setiap perbuatan ada kon sekuensinya.

Berdasarkan teori Moeslichatoen men jelaskan kelebihan metode Bermain Sambil Belajar ini mempunyai banyak nilai yang positif untuk perkembangan peserta didik, diantaranya: Permainan merupakan alat pendi dikan kemasyarakatan (pendidikan sosial), karena di sana anak belajar bergaul, beker jasama, saling menghargai, mentaati pera turan, sportivitas dan kejujuran, dalam permai nannya anak mengenal kekuatannya sendiri dibandingkan dengan kekuatan teman nya, Permainan merupakan kesempatan berekspe rimen dan bereksplorasi, dengan hasil anak mengenal-benda-benda dan sifat-sifatnya, mengenal hukum-hukum alam, dalam permai nan anak menghayati perasaan rasa senang, bebas, gembira, rasa puas atas hasil sendiri dan rasa percaya pada diri sendiri, yang semuanya baik untuk kesehatan mental dan pendidikan kepribadian.

Penelitian ini sejalan dengan peneli tian Ade holis(2016) Hasil pengujian tersebut menunjukkan bahwa terdapat per bedaan secara signifikan terhadap pening katan kreativitas dan kognitif anak usia dini pada TK Al Kautsar di Kabupaten Garut, an tara ke lompok kontrol dengan kelompok eks perimen. Karena hasil belajar melalui ber main balok unit antara kelompok kontrol dengan kelompok eksperimen mempunyai perbedaan yang signifikan terhadap pengem bangan kreativitas dan pengembangan kog nitif anak usia dini maka direkomenda sikan agar belajar melalui bermain balok unit pada TK Al Kautsar di Kabupaten Garut khusus nya di TK/RA yang ada di Kabupaten Garut pada umumnya perlu dikembangkan dengan lebih baik lagi.

\section{c. Metode Diskusi}

Dari 40 responden yang menerapkan sebanyak 29 responden(72,5\%) dan yang tidak menerapkan sebanyak 11 responden $(27,5 \%)$.

Menurut suryosubroto keuntungan metode diskusi cukup banyak, yakni me libatkan semua siswa secara langsung dalam proses belajar sehingga setiap siswa dapat menguji tingkat pengetahuan dan pengu asaanya pada mata pelajaran masing-masing ,dapat mengembangkan daya berpikir secara ilmiah dengan mengajukan dan memper tahankan pendapatnya di dalam diskusi siswa akan dapat mempercayai kemampuan diri sendiri dan dapat menunjang sikap dan usaha usaha pengembangan sikap sosial dan de mokratis siswa.

Penelitian ini sejalan dengan hasil penelitian Ermi(2015) Berdasarkan hasil penelitian tindakan kelas yang telah dila kukan dalam proses pembelajaran pada pokok bahasan perubahan sosial di kelas XII SMA Negeri 4 Pekanbaru dapat ditarik kesimpulan sebagai berikut: Penerapan metode diskusi dapat meningkatkan belajar siswa pada pokok 
bahasan perubahan sosial dalam pelajaran sosiologi siswa kelas XII SMA Negeri 4 Pekanbaru, Metode diskusi dapat mening katkan hasil belajar sosiologi materi pe rubahan sosial siswa kelas XII SMA Negeri 4 Pekanbaru. Dapat dibuktikan bahwa dari tes awal tuntas $25,71 \%$, pada siklus I kegiatan pertama tuntas menjadi $31,29 \%$ dan kegiatan kedua $40,00 \%$. Untuk kegiatan siklus 2 ke giatan pertama $77,14 \%$ dan kegiatan kedua tuntas mencapai $100 \%$. Jadi metode diskusi dapat digunakan dalam proses pembelajaran dan hasil b elajar pokok bahasan perubahan sosial sosiologi siswa kelas XII SMA Negeri 4 Pekanbaru.

\section{d. Metode Demonstrasi}

Dari 40 responden yang menerapkan sebanyak 30 responden $(75,0 \%)$ dan yang tidak menerapkan sebanyak 10 responden $(25,0 \%)$.

Menurut teori aswan zain penggu naan metode demonstrasi sangat menunjang proses interaksi mengajar belajar dikelas. Keuntungan yang diperoleh ialah dengan demonstrasi perhatian siswa lebih terpusat pada pelajaran yang sedang diberikan, kesalahan-kesalahan yang terjadi bila pelaja ran diceramahkan dapat diatasi melalui penga matan dan contoh kongkrit. Sehingga yang diterima oleh siswa lebih mendalam dan tinggal lebih lama dalam jiwanya. Jadi dengan metode demonstrasi itu siswa dapat berpartisipasi aktif dan memperoleh penga laman langsung, serta dapat mengembagkan kecakapannya walaupun demikian kita masih melihat juga kelemahan pada metode ini.

Hasil penelitian yang dilakukan sa dewa(2015) Hasil penelitian ini di dalamnya terdapat peningkatan kreativitas dan hasil belajar ansambel musik. Penggunaan metode demonstrasi dapat meningkatkan kreativitas dan hasil belajar siswa kelas VII H. Pening katan kreativitas yaitu sebagai berikut: (1) Peningkatan kreativitas antara prasiklus ke siklus I yaitu sebesar $2.5 \%$, (2) Peningkatan kreativitas antara siklus I ke siklus II sebesar $43.75 \%$. Peningkatan hasil belajar yaitu se bagai berikut: (1) Peningkatan hasil belajar antara prasiklus ke siklus I yaitu sebesar $26.87 \%$, (2) Peningkatan hasil belajar antara siklus I ke siklus II yaitu sebesar $12.5 \%$.

\section{e. Metode Bercerita}

Dari 40 responden yang menerapkan sebanyak 30 responden $(75,0 \%)$ yang tidak menerapkan sebanyak 10 responden $(25,0 \%)$.

Berdasarkan teori Sa'ad Riyadh mengatakan kegitan bercerita bisa membuat guru menceritakan dan menanamkan nilainilai positif pada anak,pengetahuan sosial ,nilai-nilai moral dan juga kegaamaan. Pelajaran sambil bercerita memberikan penga laman belajar mendengarkan pada anak membantu mengembangkan kemampuan kognitif,efektif dan psikomotorik ,mengem bangkan imajina anak,melatih daya tangkap anak,berlatih mengembangkan emosi anak ,perasaan sosial dan menjalin suasana yang akrab antara yang bercerita dan yang menden gar cerita.

Penelitian yang dilakukan oleh Indah yani dkk (2014) didapatkan hasil analisis data menunjukkan bahwa terjadi pen gembangan kemampuan berbahasa den gan menerapkan metode bercerita berbantuan media buku bergambar pada siklus I sebesar 58,07\% yang berada pada kategori rendah ternyata mengalami peningkatan pada siklus II men jadi $82,25 \%$ tergolong pada kategori tinggi. Jadi dapat disimpulkan bahwa pene rapan metode bercerita berbantuan media buku bergambar dapat meningkatkan pengem bang an kemampuan berbahasa anak kelompok B Semester II TK Titi Dharma Denpasar Tahun Pelajaran 2013/2014.

Berdasarkan asumsi peneliti dari strategi metode gambar bermain ,diskusi ,demonstrasi dan bercerita yang paling ban yak dijawab oleh orang tua adalah pertanyaan nomor 1 dan 3 pada metode disku si,1,2 dan 3 pada metode bermain, nomor 3 pada metode diskusi,nomor 5 pada metode demontstrasi, dan nomor 4 pada metode bercerita jadi alasan orang tua menggunakan metode gambar dalam pembelajaran adalah karena orang tua mengajarkan anak dengan meng gunakan gambar dan tulisan,dan anak juga 
terlihat malas dan bosan jika belajar menggunakan gambar. Pada metode bermain karena dalam pembelajaran orang tua sering menggunakan permainan dalam mengajari anak,orang tua menggunakan permainan sambil belajar untuk mengurangi stress pada anak dan orang tua juga mengajak anak bermain sambil belajar dengan semua mata pelajaran. banyak orang tua yang meng gunakan metode diskusi dikarenakan banyak orang tua yang membebaskan anaknya untuk berpendapat dalam diskusi. Dan pada metode demonstrasi dalam pembelajaran adalah karena anak terlihat semangat belajar ketika orang tua mempraktekkan materi pembe lajaran dengan menggunakan alat peraga.

Berdasarkan hasil penelitian tersebut dapat disimpulkan bahwa strategi orang tua dalam mengajar dan mendidik anak merupa kan hal utama yang sangat mempe ngaruhi terhadap kemampuan akademik anak dengan menggunakan metode gambar,metode berma in,metode diskusi,metode demontrasi,dan me tode bercerita.Pada penelitian ini orang tua banyak menggunakan metode diskusi karena banyak orang tua yang membebaskan anak nya untuk berpendapat dalam diskusi.

\section{KESIMPULAN}

Berdasarkan hasil penelitian yang telah peneliti lakukan pada tanggal 11 s/d 15 Agustus tahun 2021, dengan 40 responden tentang starategi orang tua dalam mengajar dan mendidik anak dalam pembelajaran dirumah selama pandemi covid-19 di gampong meunasah cut kecamatan peudada kabupaten bireuen, maka hasil penelitian dapat disimpulkan bahwa:Strategi metode diskusi diperoleh sebanyak 30 responden( $75,0 \%)$,Strategi metode bermain diperoleh sebanyak 28 responden (70,0\%),Strategi metode bercerita diperoleh sebanyak 28 res ponden $(70,0 \%)$,Strategi metode gambar diperoleh sebanyak 27 responden $(67,5 \%)$ ,Strategi metode demonstrasi diperoleh sebanyak 21 responden $(52,5 \%)$
Ucapan Terima Kasih kepada :

1. Terima kasih kepada institusi STIKes

Muhammadiyah Lhokseumawe

2. Terima kasih kepada tempat penelitian

\section{Daftar Pustaka}

Achmad, Y. (2020). UPDATE 25 April: Kasus Covid-19 di Indonesia Mencapai 8.607.Kompas.Com.https://nasional.k ompas.com/read/2020/04/25/

15472271/update-25-aprilkasuscovid-19-di-indonesiamencapai-8607

BBC. (2020). Virus corona: "Status Kedaruratan Kesehatan Masyarakat" dan Pembatasan Sosial Berskala Besar, yang boleh dan tidak boleh-BBC News Indonesia. BBC News Indonesia

Djalante, R., Lassa, J., Setiamarga, D., Sudjatma, A., Indrawan, M., Haryanto, B., Mahfud, C., Sinapoy, M. S., Djalante, S., Rafliana, I., Gunawan, L. A., Surtiari, G. A. K., \& Warsilah, H. (2020). Review and analysis of current responses to COVID-19 in Indonesia: Period of January to March 2020.

Kementerian Pendidikan dan Kebudayaan . 2016, Mendampingi Anak Belajar di Rumah. Jakarta: Kementerian Pendidikan dan Kebudayaan

Okmawati, M., \& Tanjak, D. (2011). Journal of English Language Teaching the use of google classroom during pandemic. 9(2).

Saputra, didin hadi. (2020). Pembelajaran Efektif Dari Rumah Berbasis Online. Universitas Nadhlatul Wathan Mataram.

Singhal, T. (2020). A Review of Coronavirus Disease-2019 (COVID-19). The 
Indian Journal of Pediatrics, 87(4): 281-286.

Wahyuningsih, S., Abbas, E. W., \& Mutiani, M. (2020). Implementation of Leadership Value of Rudy Resnawan as a Learning Resources on Social Studies. The Innovation of Social Studies Journal, 1(2), 169-177.
Zimmermann, P., dan Curtis, N. 2020. Coronavirus Infections in Children Including COVID -19. The Pediatric Infectious Disease Journal. 39(5): 355-368. 
